\title{
Environmental Management Supervision Integration Policy on Coal Mining Based on Integrated Principles
}

\author{
Nurul Listiyani ${ }^{1} \quad$ Rizka Zulfikar $^{2} \quad$ Rakhmat Nopliardy $^{1}$ \\ 1.Faculty of Law, Islamic University of Kalimantan Muhammad Arsyad Al Banjari \\ Jl. Adhyaksa No. 2 Kayutangi Banjarmasin (70123), Indonesia \\ 2. Faculty of Economic, Islamic University of Kalimantan Muhammad Arsyad Al Banjari \\ Jl. Adhyaksa No. 2 Kayutangi Banjarmasin (70123), Indonesia
}

\begin{abstract}
Applied Research Featured Higher Education (PTUPT) under Ristekdikti BRIN's grant for 2019/2020 is research to find a form of environmental management supervision policy towards coal mining that regulates the form of coordination between stakeholders, authority and supervisory objects, as well as a commitment of active role between government, business, and community in the supervision of environmental management. The results of the study are a recommendation of the South Kalimantan Provincial Legislature to make a PERDA initiative related to environmental management which is expected to be the right step to maintain a sustainable environment. The method of approach in this study is socio juridical, with qualitative and quantitative analysis methods. The results showed that both in terms of regulation and implementation, coordination of supervision implementation has not been regulated and implemented optimally, so it has not supported the realization of integrated environmental management supervision based on the principle of integrated. Based on this, it is necessary to establish an environmental management legal system in the form of local regulations whose content material contains an integrated surveillance system with a shared commitment between stakeholders.
\end{abstract}

Keywords: policy; supervision; coal mining; integrated; Coordination

DOI: $10.7176 / \mathrm{JLPG} / 103-05$

Publication date: November $30^{\text {th }} 2020$

\section{Introduction}

The reseach road map of Islamic University of Kalimantan (UNISKA) MAB has been established by determining the achievement of long-term goals, namely international impact research that is projected to be achieved in 2021-2025. In carrying out the research, the focus of the field that researchers reviewed is environmental issues which is one of the leading research areas of UNISKA MAB in 2016-2020. These environmental issues are concentrated on the protection and management of natural resources and the environment.

Personally, the research roadmap of researchers is as follows:

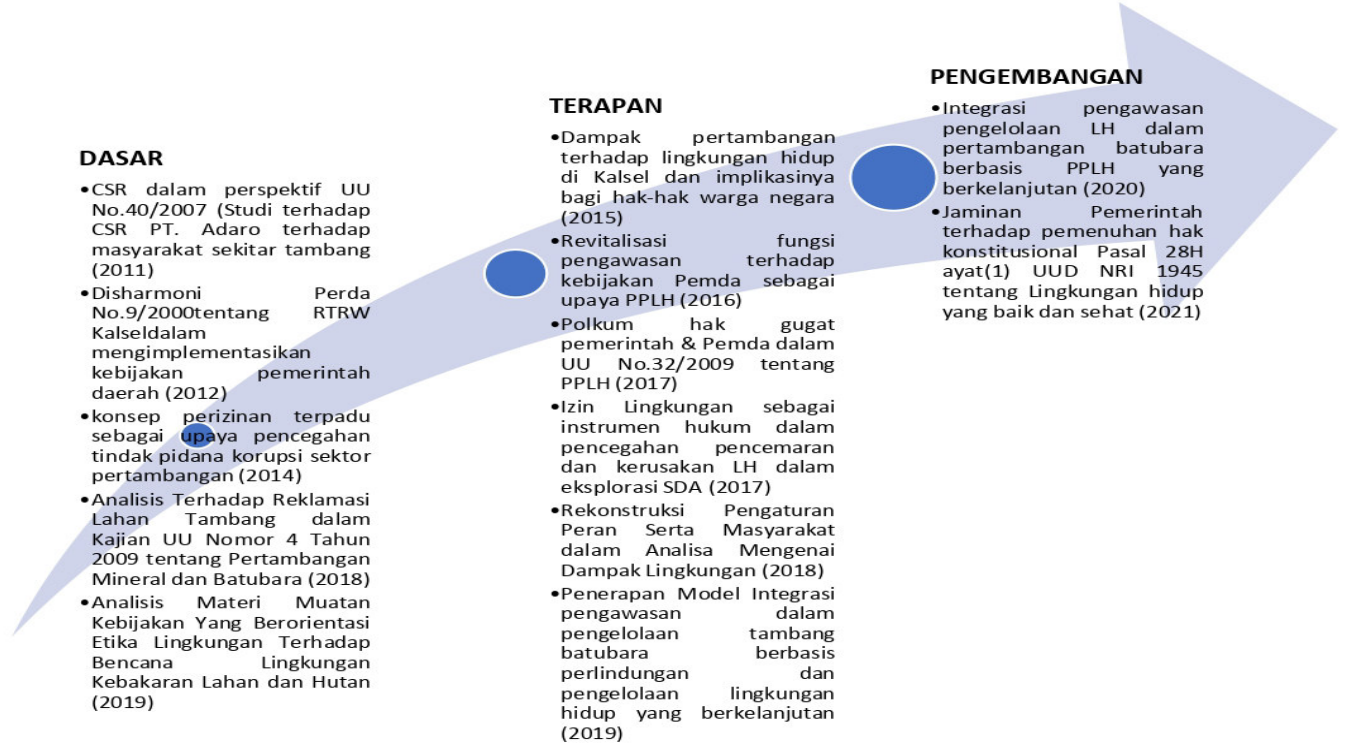

Figure 1. Research Road Map

A meeting between the Ministry of Environment and Forestry (KLHK) and regional leaders which held in 2019 , stated that 8,683 mining businesses were not licensed and many permit holders did not comply with the 
provisions of the mining environment management and monitoring obligations including reclamation and postmining under Article 96 of Law No. 4 of 2009 on Mineral and Coal Mining before the change.

Based on the meeting, it is known that the local government has made various efforts to optimize the environmental recovery of mining activities, both in terms of regulation and management side. It is just that the division of roles in the development, supervision, and restoration of the environment in mining activities still needs to be improved.

The Ministry of Agriculture proposes the need for coordination between general supervision that becomes the competence of the Ministry of Agriculture and technical supervision which is the competence of the Ministry of Energy and Mineral Resources (ESDM) and the Ministry of LHK to jointly supervise the implementation of mining provisions by local governments, including reclamation and post-mining obligations.

At the provincial level, the Head of The Kalsel Esdm Office, Isharwanto said it had only revoked 596 IUP because it did not meet CNC status (including licensing, territorial, and environmental aspects). From the data of the Kalsel ESDM Office, there was a 183-point void.

From the data in ESDM Office there are eight districts in Kalsel that contribute to the mine void. Namely Banjar, Tapin, Regency, Balangan, Tabalong, Tanah Laut, Tanah Bumbu, and Kotabaru. Kabid Mineral and Coal Dinas ESDM Kalsel, Gunawan Harjito mentioned that the area of void of all IUP holders in Kalsel is $1,579.04$ hectares.

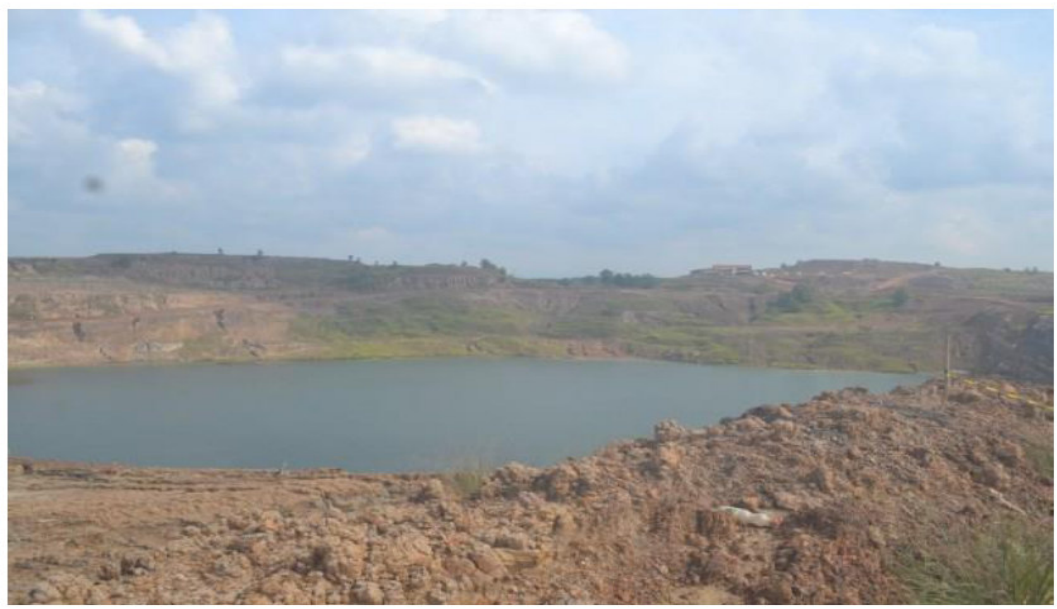

Figure 2. Mining Effect To Soil Landmark

Regarding environmental pollution, the Head of the Environment Office of South Kalimantan Province, Hanifah Dwi Nirwana, revealed that pollution problems in this area, are a very important concern for his office. Referring to the previous phase, more sides of coordination and facilities tend to be passive.

As the research that has been done by the team in the first year, the problems presented by the Head of DLHD Kalsel Province have been in line with the surveillance model whose main point is the fulfillment of indicators of coordination and synergy between the leading sectors in environmental management supervision, namely KLHK and the Ministry of Energy and The Ministry of Energy, at the regional level of the Environment Office and the Office of Esdm There has been no regulation to overcome the coordination deadlock is the main objective in this second year research. This regulation must certainly be harmonized with changes to the MINERBA Law and aligned with the current covid-19 pandemic conditions.

\section{Research Methods}

\subsection{Types of Research}

Namely sociolegal research, which is legal research that serves to see the law in real time and examine the work of the law in the community environment. This type of legal research helps researchers to analyze the implementation of environmental management surveillance models underlying the release of policy documents related to that surveillance model.

\subsection{Nature of Research}

This research is a descriptive research analysis, which is a study that traces the legal basis/regulation stipulated in the supervision of environmental management as stated in the environmental permit, reviewing to be then described in the form of a draft policy. The draft is then analyzed using the parameters of legislation, legal theory, and expert opinion (doctrine) which aims to find and obtain answers from 2 (two) subject formulations of the problem. 


\subsection{Data Type}

To obtain data in the study, researchers used 2 (two) types of data, such as :

1. Primary data, namely data obtained from field research results obtained directly from speakers in the field and the implementation of focus group discussion, as well as from respondents (field research).

2. Secondary data, data obtained from library research where researchers collect and study regulations related to environmental law policies that researchers can describe as follows:

a) Constitution 1945;

b) Law No. 23 of 2014 on Local Government;

c) Law no. 32/2009 on Environmental Protection and Management;

d) Law No. 4/2009 on Mineral and Coal Mining

e) Government Regulation No. 27/2012 on Environmental Permits.

f) Law No. 3/2020 on Changes to Law No. 4/2009 on Mineral and Coal mining

\subsection{Data Collection And Analysis Techniques}

1. Preparatory and coordination meetings

2. To collect primary data, the research team conducted direct observations on competent agencies towards the implementation and issuance of environmental management supervision policies/ regulations, namely: Regional Secretariat (Setda) of South Kalimantan Province, Setda District of Tabalongand Bumbu Land, Dinas Environment (DLH) Kalimantan Selatan province, DLH Tabalong Regency and Bumbu Land, Dinas Energid dan Mineral Resources of Kalsel Province, DPRD Kalsel Province, Tanah Bumbu Parliament. Observations are also made directly to mining companies, namely PT. Adaro Indonesia. Questionnaires are also the primary source of data. Furthermore, the results of primary data collection are brought to be a theme discussed together in the focus group discussion (FGD). FGD has a very high level of urgency to achieve thought/input/criticism to get perception equations in the process of assessment, conditioning, testing, and policy document creation.

3. To collect secondary data, researchers do so by systemizing written legal materials in the form of legislation and research results, articles in journals that have a connection to the error examined.

4. At data analysis stage, FGD results are sealed for concept and conducted public tests attended by relevant agencies and stakeholders.

\subsection{Research Sites}

In the second year, PTUPT established 2 districts to become research locus, namely Tabalong Regency and Tanah Bumbu Regency, based on the parameters of the two districts in the largest mining area in South Kalimantan Province

\section{Analysis And Discussion}

Indonesia is known around the world as a country with rich and abundant natural resources. Renewable and nonrenewable natural resources, such as watersheds, lakes, protected areas, coastal, swamp and peat areas, and others, as well as natural resources in the form of commodities (natural resource commodity )such as timber, rattan, mining minerals, oil and gas, fish, and others, are evenly distributed throughout the sovereign territory of the Unitary State of the Republic of Indonesia (NKRI). (Nurjaya, 2008).

Environmental issues mining in Indonesia is much questioned. The cause is the negative impact of mining as a result of mining businesses, damage to forests, polluted seas, disease, and community conflict in the mining circle. The immediate impact is ecological damage as well as the chance of floods and landslides.

South Kalimantan is one of the provinces that has the largest coal natural resources in Indonesia. When referring to the opinion that no mining activity does not damage the environment. Therefore, this opinion is strongly correlated with data from the Regional Disaster Management Agency (BPBD) of South Kalimantan Province which records high rates of floods and landslides in districts in South Kalimantan that have large natural resources. 
Table 1. Floods Data In Kalimantan Selatan Province During 2019

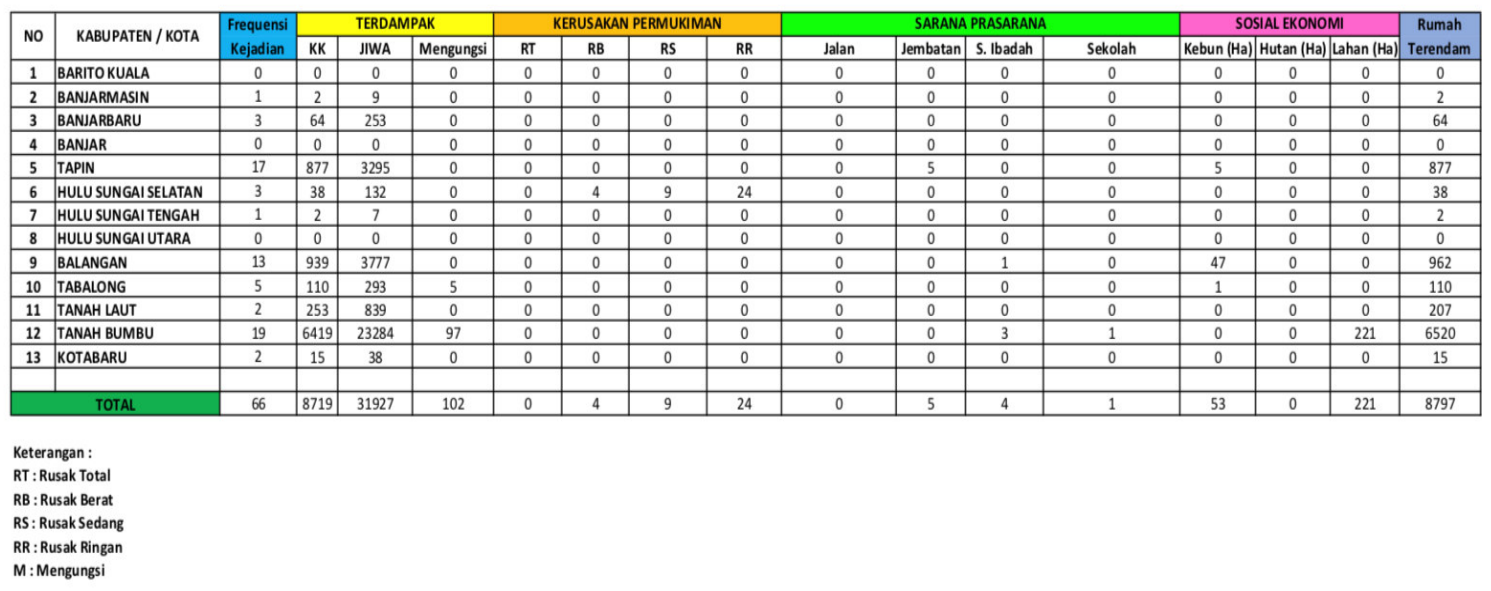

Table 2. Landslide Disaster Data In Kalimantan Selatan Province During 2019

\begin{tabular}{|c|c|c|c|c|c|c|c|c|c|c|c|c|c|}
\hline \multirow{2}{*}{ No } & \multirow{2}{*}{ KABUPATEN / KOTA } & \multicolumn{2}{|c|}{ TERDAMPAK } & \multicolumn{4}{|c|}{ KERUSAKAN PERMUKIMAN } & \multicolumn{4}{|c|}{ SARANA PRASARANA } & \multirow{2}{*}{$\begin{array}{l}\text { Frequensi } \\
\text { Kejadian }\end{array}$} & \multirow{2}{*}{$\begin{array}{l}\text { Taksiran Kerugian } \\
\text { (Rp) }\end{array}$} \\
\hline & & $\mathrm{KK}$ & JIWA & RT & RB & RS & $\mathbf{R R}$ & Jalan & Jembatan & S. Ibadah & Sekolah & & \\
\hline 1 & BARITO KUALA & 0 & 0 & 0 & 0 & 0 & 0 & 0 & 0 & 0 & 0 & 0 & Rp \\
\hline 2 & BANJARMASIN & 0 & 0 & 0 & 0 & 0 & 0 & 0 & 0 & 0 & 0 & 0 & $\mathrm{Rp}$ \\
\hline 3 & BANJARBARU & 0 & 8 & 0 & 0 & 0 & 0 & 0 & 0 & 0 & 0 & 2 & $\mathrm{Rp}$ \\
\hline 4 & BANJAR & 1 & 2 & 0 & 0 & 0 & 1 & 0 & 0 & 0 & 0 & 1 & $\mathrm{Rp}$ \\
\hline 5 & TAPIN & 0 & 0 & 0 & 0 & 0 & 0 & 0 & 0 & 0 & 0 & 0 & $\mathrm{Rp}$ \\
\hline 6 & HULU SUNGAI SELATAN & 1 & 2 & 0 & 0 & 1 & 0 & 0 & 0 & 0 & 0 & 2 & $\mathrm{Rp}$ \\
\hline 7 & HULU SUNGAI TENGAH & 0 & 0 & 0 & 0 & 0 & 0 & 0 & 0 & 0 & 0 & 0 & $\mathrm{Rp}$ \\
\hline 8 & HULU SUNGAI UTARA & 0 & 0 & 0 & 0 & 0 & 0 & 0 & 0 & 0 & 0 & 0 & $\mathrm{Rp}$ \\
\hline 9 & BALANGAN & 8 & 24 & 5 & 0 & 1 & 2 & 100 & 0 & 0 & 0 & 6 & $\mathrm{Rp}$ \\
\hline 10 & TABALONG & 0 & 0 & 0 & 0 & 0 & 0 & 170 & 0 & 0 & 0 & 2 & $\mathrm{Rp}$ \\
\hline 11 & TANAH LAUT & 0 & 0 & 0 & 0 & 0 & 0 & 0 & 0 & 0 & 0 & 0 & $R p$ \\
\hline 12 & TANAH BUMBU & 0 & 0 & 0 & 0 & 0 & 0 & 0 & 0 & 0 & 0 & 0 & $\mathrm{Rp}$ \\
\hline 13 & KOTABARU & 10 & 41 & 9 & 0 & 3 & 0 & 0 & 0 & 0 & 0 & 3 & $\mathrm{Rp}$ \\
\hline & & & & & & & & & & & & & \\
\hline & TOTAL & 20 & 77 & 14 & 0 & 5 & 3 & 270 & 0 & 0 & 0 & 16 & Rp \\
\hline
\end{tabular}

Keterangan :

RT : Rusak Total

RB : Rusak Berat

RS: Rusak Sedang

The impact sparked by pollution and damage to environmental management is generally difficult, even irreversible. Therefore, preventive functions on environmental issues stemming from business activities can be realized through a form of supervision, especially supervision in environmental aspects. The implementation of environmental supervision is a series of activities to obtain in-depth information about a business and/or activities, including the process of activities, adherence to the rules and requirements and obligations listed in the permit, and evaluation of the way of environmental management. (Listiyani, 2018).

South Kalimantan is the province that has the largest coal resources in Indonesia. The area of coal mining business license is 5,137,875.22 hectares consisting of PKP2B, KK, and IUP, with the details of permits listed in the data of the Energy Office, Mineral Resources of South Kalimantan Province, namely:

a. Coal Mining Works Agreement (PKP2B) amounted to 19 pieces

b. Contract of Works amounting to 2 pieces

c. Mining License (IUP) amounting to 373 pieces

From a normative legal perspective, it can be observed that vertical and horizontal inconsistencies in the regulation of natural resource management norms at the statutory level, namely:

1) Incompatibility (in synchronization) setting norms between sectoral legislation governing the management of natural resources with the Constitution of the State

2) Republic of Indonesia year 1945 (Constitution of the NRI year 1945); and (2) Disharmony setting norms between legislation governing the management of natural resources.

Furthermore, empiric facts show that there is a tendency to weaken the intensity of the implementation of supervision and this has an impact on the un-realization of environmental protection and management goals to the maximum. The main effort that must be made in environmental management is the prevention of pollution and environmental damage, which in article 1 number (2) of UU PPLH states that one of the prevention efforts is to conduct systematic and integrated supervision.

Edith Brown Weiss states that prevention and mitigation are two tools used for environmental protection. Prevention principles aim to prevent specific damages arising, such as from environmental changes, damage to people or the environment, or burdens that exceed the capacity of the environment to receive them. The principle 
of prevention is a fundamental principle in environmental protection efforts because, with a preventive approach, the parties are required to carry out "due diligence". In other words, take appropriate and in good faith actions and regulate public or private activities within its jurisdiction or control the possibility of environmental hazards. Environmental law enforcement efforts should only be used when environmental pollution prevention efforts are not effective. (Effendi, 2011)

In the study conducted by the research team of Ristekdikti BRIN grant recipients in 2019/2020, then based on qualitative data collected at the focus group discussion stage attended by stakeholders (Provincial and District Representative Councils, South Kalimantan Provincial Government, Environment Office, Energy, and Mineral Resources Office, District Government, mine actors, non-governmental organizations and research partners), found important points that have urgency regulated in the material of life management supervision of coal mining, namely the need for coordination in supervision from the planning stage, a commitment between leading sector supervision and supervisory authority.

\subsection{Coordination of Supervision}

Environmental protection and management are carried out comprehensively, including planning, utilization, control, maintenance, supervision, and enforcement. This affirmation is based on the consideration that environmental issues should be used a comprehensive approach, ranging from upstream to downstream, ranging from planning to law enforcement where the issues of each stage are seen as interconnected and contribute to environmental issues. Therefore at each stage, several instruments can be used, namely at the planning stage of the introduction of environmental inventory, the division of the ecoregion region, to the environmental protection and management plan that must be integrated into the long and medium-term development plan, both at the national and regional level. Planning is necessary to initiate the implementation of supervision to realize the will of the law containing orders and prohibitions in the field of mining.

Mining businesses in the form of applicable technically cannot be released from other government agencies in a cross-sectoral way. This means that the overall implementation of the mining business should always involve government agencies in a cross-sectoral way for the sustainability of such activities, especially related to performance related to environmental management supervision. The expectation of the involvement of this agency is intended as a realization of the publication of IUP, both IUP Exploration and IUP Production operations which are instruments of law enforcement in the mining area. Therefore, ideally, environmentallyminded management is expected to be realized if synergistic working relationships are established between agencies in the form of coordination.

However, this has not been very apparent in the field between sectoral agencies, for example in Tabalong Regency there is an IUP of coal mining activities issued by permits, whereas in reporting the company of the owner of the IUP has not fulfilled its obligation to submit a report RKL-RPLperiodically every 6 months to the Office of the Environment since holding an environmental permit, so there needs to be good coordination and communication between sectoral agencies in the issuance of mining business permits. This reality is one of the obstacles in making surveillance an instrument of the law enforcement because it does not reflect the integrated and still sectoral nature and the intertwining of coordination and communication between agencies with each other. (Zahriati, 2020)

Coordination is essentially an act of cooperation to obtain information harmony that will ultimately result in good cooperation between all parties. Coordination becomes indispensable concerning mining businesses, because in its implementation related to the requirements of various forms of licensing that are not only the authority of technical agencies in this case the Office of ESDM but related to other sectoral agencies. This connection seems in some ways about licensing. For example, related to environmental permits involving other agencies, namely Dinsa Lingkungan Lingkungan. Therefore it is necessary to regulate the legal norms that are expressly governed. At the operational stage, it is necessary to understand the same from various parties, especially the law enforcement in the field related to the intended matters. Coordination is necessary for synergy and especially in addressing environmental issues.

Coordination from the initial planning stage is needed to produce input and perception useful for the public interest to improve the quality in the series with environmental decision making. Therefore, ideally, the coordination system should also be formulated from the beginning. (Puluhulawa, 2010).

Given the complexity of environmental management and vibrant mining business problems carried out by the person in charge of the business and/ or mining activities, it has an impact on environmental damage. The Local Government can implement the Authority and Policy for the management and prevention of mining consequences with the principle of sustainable development. Legal efforts taken to solve environmental management and law enforcement issues and the implementation of sanctions expressly in the mining sector by coordinating prevention and countermeasures due to coal mining are needed at the central and regional levels. (Hanafi, 2020)

With various Laws and Regulations of the Republic of Indonesia from all aspects both the Laws of the 
Republic of Indonesia No. 4 of 2009 on Mineral and Coal Mining and The Law of the Republic of Indonesia No. 32 of 2009 on environmental protection and management that have been in effect can solve a variety of serious problems, ranging from violations of the law and uncontrollable environmental damage.

Pay attention to some of these things above the need to coordinate the Environment Office with the Esdm Office in terms of environmental supervision in terms of:

1. Coordination to ensure that RKAB and CTRtl are issued by ESDM before the document AMDAL UKL UPL, the environmental permit exists and has been issued can be exploration and must be informed to the Provincial DLH and Kab / Kota.

2. Coordination and information related to the guarantee of reclamation should be coordinated with DLH as a reclamation and revegetation monitoring agency in both Prov and Kab/Kota.

3. Coordination For post-mining ensure that environmental management studies must be made by mining companies, before 2 years of operation, to ensure the benefits of post-mining land in Kab / Kota.

Furthermore, if there are problems with environmental cases technically, coordination needs to be done related to:

1. Implementation of pollution management and termination of the source of polluters against corporations as responsible for business and/or activities.

2. Implementation of recovery against pollution (cleaning, remediation, rehabilitation, and restoration) of polluted sources.

3. Development of information systems and conditions against potential impacts.

4. Implementation of protection of natural resources and supervision of natural resources and their arrangements.

\subsection{Commitment}

One important principle in the management of natural resources and the environment, which is intended to prevent pollution and/or destruction of natural resources and the environment, is the principle of the precautionary principle. The philosophical meaning of the principle of prudence is natural resources as living systems or ecological systems that give life to living things, especially humans. If one sub ecological system is polluted or damaged it will affect the other subsystem and disrupt the ecological balance that can ultimately negatively affect and threaten the lives of living things, especially humans. Therefore, humans should be careful to treat their environment and natural resources that give life to humans. (Keraf, 2010) The environment should be treated like it treats itself by humans. It is better to prevent early before pollution and/or damage to natural and environmental sources than to overcome and recover after they occur. In the General Explanation of Law No. 32 of 2009 on Environmental Protection and Management, it is mentioned, that preventive enforcement of the law to prevent pollution and environmental damage can be done through surveillance instruments and licensing.

Planning supervision in sectoral agencies related to environmental management supervision is carried out individually by each ESDM agency with the Office of Environment, ideally, supervision planning is carried out in an integrated manner so that it essentially plays an important role in and determines the optimal implementation of supervision.

Therefore through integrated supervision planning, a joint commitment is required, similar perceptions, so that it is expected that the entire set of supervision can be carried out following the targets set in an integrated manner through supervision planning so that administrative law enforcement efforts can be implemented. Through integrated supervision, it is expected that its implementation does not deviate from the rights and objectives of supervision.

According to Abrar Saleng, The principles of supervision from the perspective of administrative law is the control of an activity carried out by a government agency that is given the task of overseeing by the legislation. (Saleng, 2004) The field of supervision is the duty of government agencies, so it is strongly related to administrative law.

The close relationship between environmental regulations in the field of mining issued by the Ministry of Energy and Mineral Resources and environmental regulations issued by the Ministry of Environment should never contradict and run harmoniously. The core alignment and spirit contained in the clauses in each field of mining and the environment are not always harmonious in practice. One example that can occur is such as the enforcement of environmental law in the form of the application of administrative sanctions in the form of Government Coercion for the termination of production operations issued by the Environment Agency against mining businesses that do not meet the compliance values that have been set by regulations sometimes ignored by the Department of Energy and Mineral Resources (mining) while keeping the company concerned to continue operating as usual. (Saleh, 2020)

Another example is when the Environment Agency directs mining businesses to immediately conduct rehabilitation (reclamation and revegetation) efforts against a disturbed land and become a source of pollution apparently in the RKAB document that has been approved by the Department of Energy and Mineral Resources 
of the area /location is not included in the reclamation and revegetation plan.

The cause of this situation is because there is still a sectoral ego both in the service and from the person /individual supervisor (knowledge and experience factor) who holds decisions in each sector. After all, it feels incompatible with its desires. (Shahrojat, 2020).

Furthermore, the community as part of the environment that is one of the affected components in mining activities, has rights and obligations to the environment is good and healthy, and should maintain and protect the environment. Community participation in environmental protection and management has been regulated in the UU PPLH. (UU PPLH, 2009)

The principle of genuine public participation provides the widest opportunity to the community and all stakeholders to take part actively, starting from the stage of identification and inventory, planning, implementation, monitoring, and supervision of the implementation of natural resource management policies.

\subsection{Integrated Environmental Management Supervision Area Policy Based on Integrated Azas}

Issuing environmental issues as a result of mining activities has not only occurred in Indonesia but has become a serious problem globally. (Hon \& Preston, 2018). Given that a good and healthy environment is the primary basic human need, therefore its fulfillment becomes part of human rights, so normatively it becomes the responsibility of the state that already has the mandate to carry out its fulfillment process constitutionally. The framework is then legitimized by the 1945 NRI Constitution, which expressly regulates the state obligation to advance ( to promote), protect, and fulfill (to fulfill) the constitutional rights of citizens to meet their basic needs. (Safa'at, 2013).

The principle of integration in environmental protection and management has also been mentioned in the Rio Declaration, which expressly mentions the principle of integration which states"environmental protection shall constitute an integral part of the development process and cannot be considered in isolation from it". Integrated ness relates to planning, implementation, and supervision. The integrated also includes spatial layout, protection of environmental resources, and integrated management at the levels of government, namely central and regional.

Conceptually, the two above understandings, namely the understanding of integration and integration, clearly show the scope of the environment that is integral (one unity / integrated). The concept then has consequences on the scope of environmental management, including the scope of environmental management supervision systems

The Academic Text of RUUPPLH does not list the principles of integrating into the implementation of environmental management, but implicitly the principle of integrating that is then contained in Law No. 32 of 2009 on UUPPLH, presented in the Academic Text of RUUPPLH, as follows:

Environmental management laws are laws that form the basis of reference for each activity that will provide a reference for any activity that will have an impact on the environment. Thus, it is appropriate if other laws governing such activities, such as mining, plantations, forestry, fisheries, manufacturing industry, transportation, and others, are formulated and applied harmoniously with environmental management laws. On the other hand, the formulation and implementation of Environmental management laws should take into account other aspects of development so that development manifests itself that integrates ecological, economic, and social aspects (sustainable development).

When observed the content material in the Academic Text of RUU-PLH above, is a description of the principle of integrating which is one of the principles in the implementation of environmental protection and management contained in Law No. 32 of 2009 on Environmental Protection and Management. In the explanation article after article UU-PLH formulated that the principle of integrated is that "protection and management of the environment are carried out by combining various elements or disapproving various related components".

Furthermore, the General Explanation of UU-PPLH implicitly also states the principle of the integrated of sentences: it is necessary to develop a legal system of protection and management of the environment that is clear, firm, and thorough to ensure legal certainty as a basis for the protection and management of natural resources and other development activities.

Based on these concepts, UUPPLH is a positive environmental law that is comprehensive and integrated for all environmental protection and management systems in Indonesia. Consequently, all competent sectors and institutions to protect and manage the environment are based on the integration in the UU-PPLH, including the coal mining sector, which in its design has a close connection to the environment.

Mochtar Kusumaatmaja at the BPHN Seminar in 1997 which was quoted by Koesnadi Hardjosoemantri, stated that a comprehensive integrated or intact approach system must be applied by law to be able to regulate the human environment appropriately and well. Integrated environmental supervision arrangements are a form of government policy following its authority in the framework of environmental protection and management.

Ideally with the principle of integrated, creating a legal system in the form of local regulations governing 
aspects of environmental law of the sectors, one of which regulates the material of environmental management supervision.

The mandate wedge between Law No. 4 of 2009 and its amendment and Law No. 32 of 2009 on PPLH and Law No. 23 of 2014 can be a strong foundation for pioneering surveillance strategies in collaboration with various parties including district/ city governments, village governments, civil society organizations, and community groups directly affected by mining activities.

The disharmony of this practice is certainly a matter of future evaluation for regulators and executors of both the mining sector and the environmental sector because the breath and spirit of each regulation is certainly the good intention, namely the achievement of the devout and environmentally friendly mining business and fulfilling the practice of good mining practice in which there is an aspect of prioritizing environmental obedience.

The effectiveness of the supervision results can go well if the results of the supervision recommendations there is a synergy between institutions, the results of supervision have collaborated with sanctions and operational licensing, the result of supervisory activities by the Environment Office gives influence to the Office of Energy and Mineral Resources as well as vice versa to strengthen each other's institutions.

It can also avoid the politics of Divided at Impera mining businesses that can ultimately direct the perpetrators of mining activities to comply with the prevailing laws and regulations in conducting mining management so that it can achieve optimal conditions in the protection and management of the environment in mining activities.

\section{Conclusion}

In the Regional Policy governing integrated environmental management supervision, there needs to be a synergistic approach between stakeholders. The synergy approach means that the mining supervision framework is designed and held together with the district government and the village government (community) through a pattern of assistance tasks. Integration is a cross-sectoral surveillance approach that is to put porta supervision. as an integral part of environmental protection and management. Meanwhile, a collaboration between local governments and resources outside local government institutions such as civil society groups and affected communities aims to strengthen participation in supervision.

Because in Law No. 4 of 2009 with its amendments and Law No. 32 of 2009 on PPLH equally mandates for further regulatory procedures of supervision regulated with $\mathrm{pp}$, it is recommended to regulators to make regulations/policies governing supervision can be governed by all relevant sector institutions, as stipulated in Article 2 of the 2009 ActppLH on state responsibility in terms of Environmental Protection and Management implemented one of which is based on the principle of integrated, namely the protection and management of the environment is carried out by combining various elements or dis-genuine various related components.

With integrated and synergistic and well-coordinated supervision between relevant sector agencies in South Kalimantan, the supervision of coal mining activities is expected to be an indicator of the success of Environmental Management Supervision produced among others:

1. Increasing number of businesses that are obedient in environmental management following environmental permits issued

2. Increasing number of businesses and /or activities(mining) who obey and can apply environmental documents

3. Increasing the commitment of stakeholders in environmental conservation efforts

4. Increased awareness of businesses/activities to comply with environmental laws and regulations

\section{References}

Saleng, A. (2004). Hukum Pertambangan. Yogyakarta: UII Press.

Hadjon, P. M. (1995). Penegakan Hukum Administrasi dalam Pengelolaan Lingkungan . Kuliah Umum UII Yogyakarta (p. 1). Yogyakarta: UII Yogyakarta.

Nurjaya, I. N. (2008). Pengelolaan Sumber Daya Alam dalam Perspektif Antropologi Hukum (1 ed.). Jakarta: Penakita Publisher.

Listiyani, N. (2018). Penormaan Pengawasan Izin Lingkungan dalam pencegahan Pencemaran dan Kerusakan Lingkungan Hidup dalam Eksploitasi Sumber Daya Alam. Media Hukum, 217-227.

Jazim Hamidi, M. L. (2009, April). Eksistensi Komisi Ombudsman Nasional dalam Mewujudkan Good Governance. Hukum Varia Peradilan, p. 47.

Effendi, A. (2011). Penyelesaian Kasus Pencemaran dari Aspek Hukum Lingkungan (The Settlement of Environmental Pollution from Environmental Law Aspect). Risalah Hukum, 26.

Puluhulawa, F. (2010). Substansi HUkum Tentang Pengawasan Izin Pada Usaha Pertambangan. Pelangi Ilmu, 148.

Zahriati, N. (2020, September, Wednesday). Koordinasi dan Komitmen Dalam Pengawasan. (N. Listiyani, 
Interviewer)

Hanafi, A. (2020, September Tuesday ). Koordinasi mutlak diperlukan dalam pengawasan. (N. Listiyani, Interviewer)

Syahrojat. (2020, Agustus Wednesday). Komitmen instansi sektor untuk mencapai tujuan pengawasan yang maksimal. (N. Listiyani, Interviewer)

Saleh, M. (2020, September Thursday). Focus Group Discussion PTUPT. (N. Listiyani, Interviewer)

UUPPLH. (2009). Undang-Undang Nomor 32 Tahun 2009 tentang Perlindungan dan Pengelolaan Lingkungan Hidup. Jakarta.

Keraf, A. S. (2010). Etika Lingkungan. Jakarta: PT. Kompas Media Nusantara.

Hon, T., \& Preston, J. B. (2018). Environment Justice and Land Use Conflict: The Governance of Mineral and Gas Resouce Development. Journal of Energy \& Natural Resources Law, 364-369.

Safa'at, R. (2013). Rekonstruksi Politik HUkum Panga, dari Ketahanan Pangan ke Kedaulatan Pangan. Malang: UB. Press. 